\title{
PEMBUATAN TEMPAT SAMPAH
}

NURUL INDARSIH

9173770410137

nurullindarsihh@gmail.com

1. Bentuk kegiatan

Pembuatan tempat sampah.

2. Lokasi

Desa Bontocini

3. Hari/tanggal dan waktu

Rabu, 30/09/2020 - 03/10/2020

4. Peserta yang di libatkan

Mahasiswa KKLP YAPTI JENEPONTO

Karang taruna

5. Alasan diadakannya

Alasan diadakannya kegiatan ini, karena melihat tidak ada tempat sampah umum Untuk menampung sampah-sampah yang ada di sepanjang jalan dan pekarangan rumah masyarakat.

6. Tujuan dan Manfaat

Tujuan dan manfaat pembuatan tempat sampah ini untuk memudahkan masyarakat membuang sampah rumah tangganya. Agar tidak lagi

membuangnya ke sembarang tempat.

7. Produk yang Dihasilkan

Tempat sampah sebanyak 6 buah.

8. Deskripsi Kegiatan

Pembuatan tempat sampah ini dikerjakan selama 4 hari yaitu pada 
tanggal 30 September pengambilan bambu, 1 oktober pembersihan

bambu, 2 oktober proses pembuatan tempat sampah, selesai pada

tanggal 3 oktober dan dibagikan pada tanggal 8 oktober. 